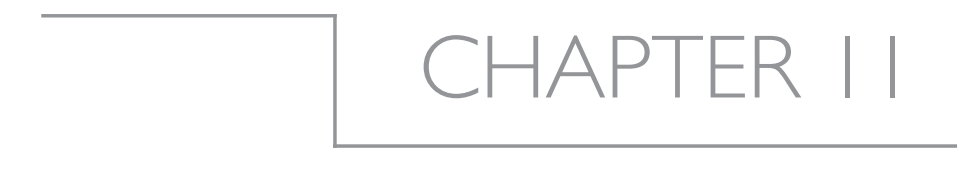

\title{
REGIONAL MEMBERSHIP: BIOGEOGRAPHY
}

\section{Steven L. Chown, David J. Marshall and Evgeny A. Pakhomov}

The geological and climatological histories of the Prince Edward Islands are, to a first approximation, well known. Marion Island is at least half a million years old, and Prince Edward Island is probably younger (McDougall et al. 2001; Boelhouwers et al. 2008). Both islands are volcanic and are considered to represent the summits of a coalescing, basalt shield volcano, located $900 \mathrm{~km}$ to the west of the closest land, the geologically more heterogeneous, and in some cases much older, Crozet Islands. At no time have the islands been part of or connected to other large land masses in the Southern Ocean. From a biogeographic perspective they are therefore truly oceanic islands (Darlington 1957; Brown \& Lomolino 1998; Whittaker 1998). Nonetheless, their histories have not been quiet, but have been characterized by isostasy, changing sea levels, considerable glaciation, and vulcanism following glacial retreat. The climatic change responsible for the growth and retreat of the glaciers characterized the entire planet (Jouzel et al. 1993), and had major effects across the majority of the Southern Ocean islands, including Marion Island, but perhaps not Prince Edward Island to the same extent (Hall 1979, 1990).

This history has, to a large degree, influenced the identities, and therefore biogeographic relationships of both the marine and terrestrial plants and animals that occur at the islands, and that have occurred there in the past. The biogeography of the biota is, in this sense, well known and simple to interpret.

\section{S.L. Chown $\&$ P.W. Froneman (eds.) The Prince Edward Islands $\bullet$ Land-Sea Interactions in a Changing Ecosystem, 277-300}


The overwhelming majority of the groups share their closest relationships with islands that are located close by: specifically the Crozet archipelago, Kerguelen Islands, and Heard and McDonald Islands. For example, with the exception of the fern Elaphoglossum randii, all of the indigenous vascular plant species that occur on the Prince Edward Islands are also found on Iles Grozet (Gremmen 1981), and E. randii also occurs on the Kerguelen Islands. Endemism to the Prince Edward Islands is higher amongst the bryophytes, but the patterns, as much as they can be discerned, are little different to those found in vascular plants (Gremmen \& Smith 2008). Amongst the insects, the Ectemnorhinus group of weevils, the moth genera Pringleophaga and Embryonopis, the fly genera Apetaenus, Telmatogeton, and Paractora, and the psocid genus Antarctopsocus all share species or sister species with the Crozet archipelago and often with Kerguelen, Heard and McDonald islands (Jeannel 1964; Gressitt 1970; Morrone 1998; Delettre et al. 2003). The springtails, mites, molluscs, freshwater crustaceans, tardigrades, and spiders show comparable biogeographic relationships (Deharveng 1981; Pugh 1993; McInnes \& Pugh 1998; Marshall et al. 1999; Pugh et al. 2002; Pugh \& Scott 2002; Pugh 2004). Although the pelagic birds and mammals range more widely, similar biogeographic relationships characterize these groups (Barrat \& Mougin 1974). The biogeography of marine benthic taxa, especially those of the shelf, near shore and littoral zones, differs little to that of the terrestrial species. The closest ties are with the Falklands, Crozet archipelago and with Kerguelen and Heard islands (Branch et al. 1991a, b, 1993; Branch 1994). For pelagic taxa the situation is quite different. Water circulation keeps pelagic organisms and larval stages of benthic species within appropriate water masses allowing completion of their entire life cycle or wide dispersion of larvae, and forms the basis for a species distributional range (Beklemishev 1969; Van der Spoel \& Heyman 1983). Since the opening of the Drake Passage and subsequent establishment of the Antarctic Circumpolar Current (ACG) 30-34 million years ago (Livemore et al. 2005), the ACC system has been a primary factor regulating pelagic species distribution patterns (Beklemishev 1969). As a consequence, no holoplanktonic endemism has been recorded around the Prince Edward Islands (Allanson et al. 1985; Boden \& Reid 1989). Overall, the close relationships between the biotas of the Prince Edward Islands, Crozet archipelago, Kerguelen Islands, and Heard and McDonald Islands have long been recognized, such that these archipelagos are considered a biogeographic unit known either as the Kerguelen Biogeographic Province (Crafford et al. 1986), or the South Indian Ocean Province Islands (Lewis Smith 1984).

Nonetheless, the biota of the Prince Edward Islands also shows links to other areas. Several taxa are shared to the west with South Georgia and with the Scotia Arc islands, including several ameronothrid mite genera (e.g. Halozetes, Alaskozetes), a number of springtails (e.g. Cryptopygus antarcticus, but see Stevens et al. 2006), flies such as those in the genus Paractora, and several plant taxa (e.g. Colobanthus, Caryophyllaceae). Biogeographic similarities to the east, with Macquarie Island and the New Zealand sub-Antarctic islands (Campbell, Auckland, Snares, Antipodes, Bounty) are also apparent, and in several cases, 
genera of both plants and insects are circum-Antarctic in their distributions (Gressitt 1970; Greene \& Walton 1975; Edgar \& Connor 2000). Relationships with islands to the North (St. Paul, Amsterdam, Gough Islands) are typically less pronounced, although these tend to be stronger for highly mobile taxa such as marine pelagic species and spore-dispersed bryophytes (Muñoz et al. 2004), than for benthic and less mobile terrestrial groups. As is the case with the terrestrial biota, benthic crustaceans, polychaetes, mollusca and echinodermata as well as bottom-dwelling fish on the Prince Edward Islands plateau are closely linked to the Kerguelen and Crozet islands and moderately to Falklands, South Georgia and even Antarctic Peninsula regions (Branch et al. 1991a, b, 1993; Eastman 1993; Branch 1994; Andrássy 1998). The distributions of the marine assemblages are highly dynamic and also depend to a large degree on prevailing marine frontal conditions (Pakhomov \& Chown 2003).

What precisely the relationships of past biotas were is difficult to determine because so little is known about them. In terrestrial habitats, the flora, and what is known of the fauna, were similar, at least over the past 16000 years, and probably also during previous interglacials, to what they are today (Scott \& Hall 1983). Palynological records suggest that previous interglacials may have included currently absent species such as Cardamine, and that during glacial periods much of the vascular flora was either absent, or restricted to refugia (probably only the cushion-plant Azorella selago) (Scott \& Hall 1983). For marine species, paleontological evidence of their past distributions is absent. It is unlikely that the current marine fauna would be different from that during previous several intergracials. Over the short term, marine species distribution to a large extent depends on frontal positions because their circum-Antarctic distributional range may undergo marked changes as a result of climatic events, or may be related to the propagation of frontal spinouts or vagrant eddies (Gorodkov 1990; Pakhomov \& Chown 2003). This is evident from the number of sub-tropical species of holoplankton (e.g. the pteropod Cymbulia sp. or amphipod Phronima sedentaria) found between the islands and fish (e.g. Brama brama) caught during the long-line fishing in the proximity of the islands (Pakhomov \& Froneman 2000; Watkins, personal communication).

Therefore, at least on initial inspection, the biogeography of the Prince Edward Islands would appear almost entirely uncomplicated and fully resolved. However, this resolution is, to a large extent, illusory. The relationships of the faunas of the South Indian Ocean Province Islands to other islands and continents are controversial (Morrone 1998; Cox 2001). Indeed, the biogeography of the Southern Ocean islands as a whole (Fig. 11.1) is contentious, from both the historical and ecological perspectives (Holdgate 1960; Skottsberg 1960; Abbott 1974; Chown 1990a; Van de Vijver \& Beyens 1999; Selmi \& Boulinier 2001). It is also confounded by the fact that humans have been moving back and forth between the islands, and between the islands and surrounding southern continents, for centuries (Headland 1989), introducing and moving species around as part of their activities (Frenot et al. 2005). In some cases 
these dispersal events are easily detected and have been correctly attributed to human activity (Slabber \& Chown 2002; Gaston et al. 2003), but in others the situation is more complex (Barnes 2002; Smith 2002; Lewis et al. 2003). Furthermore, even on the supposedly well explored Marion Island (Hänel \& Chown 1999), new genetic techniques are revealing a colonization history and spatial structure to populations that has not previously been recognized, but which is clearly coupled to the island's geological and climatological histories (Mortimer \& Jansen Van Vuuren 2006; Myburgh et al. 2007).

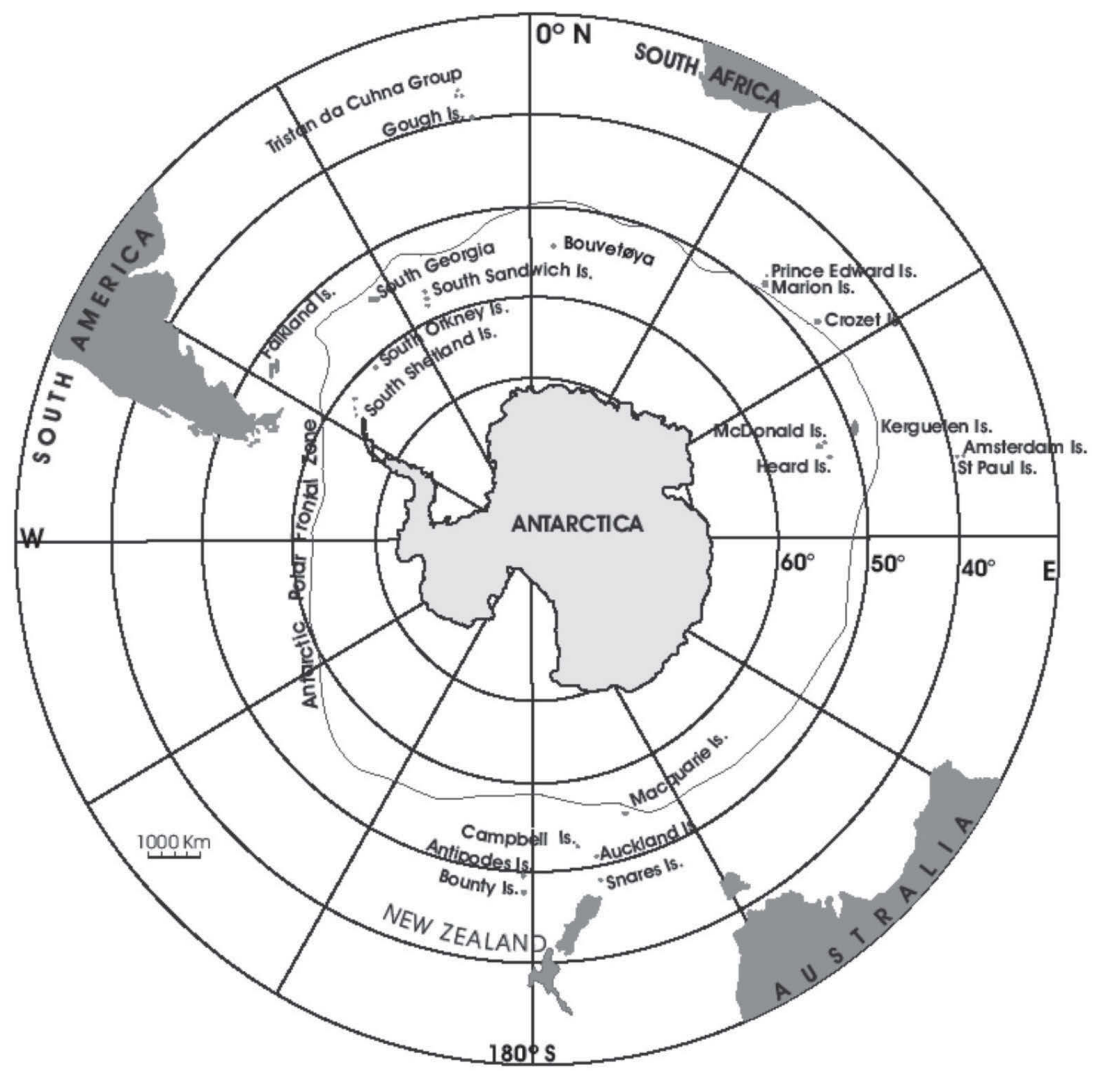

Figure 11.1 The islands of the Southern Ocean in the context of Antarctica and the southern continents.

\section{II.I Historical biogeography: an ongoing conundrum}

The biogeography of the Southern Ocean islands has been the subject of controversy for nearly 50 years (Brundin 1966; Darlington 1970). On the one hand, it has been suggested that all of the islands share enough history and a sufficient proportion of their biotas to be considered a single biogeographic province (Holdgate 1960; Skottsberg 1960; Barrat \& Mougin 1974; Chown et al. 1998; Van de Vijver \& Beyens 1999), often known as Insulantarctica (Udvardy 1987). The other, and perhaps more widely accepted, multi-regional, view is that these similarities are not large enough to warrant inclusion of 
the biotas within a single biogeographic province. Proponents of the multiregional hypothesis argue that across the Southern Ocean, island biotas differ substantially in their origins, histories, source areas, and endemicity (Gressitt 1970; Kuschel 1971; Lewis Smith 1984; Chown 1994; Morrone 1998; Cox 2001; Broughton \& McAdam 2002), and as a consequence there are considerable regional differences in the structure and composition of the biotas.

Despite several recent analyses, the question of the origin and relationships of the Southern Ocean Island biotas appears to have done little but shift back and forth between these competing hypotheses, providing no convincing argument why either of the ideas should enjoy primacy. Whilst the obvious solution to these problems might seem to be a concerted, multitaxon phylogeographic study of the region, too few marine and terrestrial taxa have been examined in sufficient detail for this to be done at present (though see Bargelloni et al. 2000; Stevens et al. 2006). Moreover, the results of such an analysis might also be subject to domination by the most speciose taxa. Recently, however, nestedness analyses of a subset of terrestrial taxa have provided considerable insight into both this conundrum and the ways in which it might be solved (Greve et al. 2005).

A perfectly nested distribution, based on species incidences, is one in which species occurring at the site of interest are always present in a more speciesrich site, whereas species absent from the site of interest never occur in a more depauperate one (Patterson \& Atmar 1986). In the Insulantarctica scenario, significant nestedness might be expected, at least at a generic level, owing to similarities in the source pool of colonists across the region, or to vicariance of a once larger landmass. The latter idea has been proposed on several occasions (Jeannel 1964; see also Brundin 1966), but it is clearly incompatible with the geological history of the region as a whole (Beggs et al. 1990; LeMasurier \& Thompson 1990; Marshall 1994; Wallace et al. 2002). Thus, a vicariant origin of the biotas is unlikely. Colonization and subsequent extinction or speciation would thus seem more plausible as causal mechanisms for nestedness if it were found. Given sufficient time, species' ranges can change markedly as a consequence of dispersal, speciation and extinction (Gaston \& Chown 1999). In the case of the Southern Ocean islands, long-distance colonization events appear to be more plausible than once thought (e.g. Valdebenito et al. 1990; Wagstaff \& Garnock-Jones 1998; Bargelloni et al. 2000; Kennedy \& Spencer 2000; Anderson et al. 2001; Burg \& Croxall 2001; Lockhart et al. 2001; McDowall 2002; Richardson et al. 2003; Muñoz et al. 2004; Grobler et al. 2006; Stevens et al. 2006), thus forming a potential mechanism for nestedness if it were found. Following colonization, speciation will reduce nestedness at the species level, whilst extinction might be expected to increase it (Lomolino 1996). However, the ranges of higher taxonomic levels, such as genera, are likely to remain more stable than those of species (Wright et al. 1998; Gaston \& Chown 1999). Therefore, across the region, nestedness should be much stronger at the generic than at the species level in the Insulantarctica scenario. 
Alternatively, in the multi-regional scenario, differences in endemicity, source pools and biogeographic history are likely to mean little in the way of significant nestedness across the Southern Ocean islands (as here defined), at either the generic or species levels. However, within a particular archipelago, significant nestedness should not only occur, but should also be very much greater than that found across the region.

Of course, because one of the mechanisms underlying nestedness is differential colonization ability, the extent of nestedness should vary considerably with the dispersal ability of the taxon concerned: organisms with poor dispersal abilities are apt to show much less nestedness than taxa with well-developed dispersal abilities (Greve et al. 2005). In the case of the Southern Ocean island taxa for which comprehensive information on distributions is available (Chown et al. 1998), nestedness might be expected to increase in likelihood as follows: insects < vascular plants < land birds < seabirds, inter-island benthos and fish $<$ holoplankton, whilst acknowledging that within each of these groups dispersal ability will vary considerably. Moreover, because most nonindigenous species are likely to have been introduced directly by humans, or are likely to have colonised other parts within an archipelago following their introduction by humans to one or more islands (or to a source area), a different set of expectations might apply to alien species by comparison with the those indigenous to the islands. Given the mostly European origins of the majority of the non-indigenous species on Southern Ocean islands (Frenot et al. 2005), it might be expected that nestedness would be considerably higher across the Southern Ocean islands for these species than for the indigenous ones, that there would be little difference between the nestedness of alien species and genera, and that vagility might not significantly influence nestedness across the Southern Ocean islands, but would do so for individual archipelagos.

In the indigenous species, considerable nestedness has been found at the species and generic levels across the region, and substantial differences also exist between nestedness at this scale and within archipelagos (specifically the New Zealand sub-Antarctic islands) (Greve et al. 2005). Thus, both the Insulantarctic and multi-regional scenarios appear to enjoy support, which is perhaps not surprising given the complexity of the region (Gressitt 1970). However, much of this complexity might be a consequence of differences of vagility of the groups (insects, vascular plants, land birds, seabirds). Highly mobile taxa, such as seabirds, that, at least in some instances, have demonstrably panmictic populations in the region (Burg \& Croxall 2001), show considerable nestedness. By contrast, less mobile taxa, such as the insects, are hardly nested at all when compared to both the seabirds and to assemblages from elsewhere (see Wright et al. 1998). In consequence, distribution patterns shown by groups with poor dispersal ability, such as weevils (Morrone 1998), are dominated by the influence of regional source pools (i.e. continental areas and large islands located close to particular archipelagos), thus providing support for a multiregional hypothesis, whilst the distribution patterns of more mobile taxa are less subject to this constraint (Barrat \& Mougin 1974) (Fig. 11.2). 

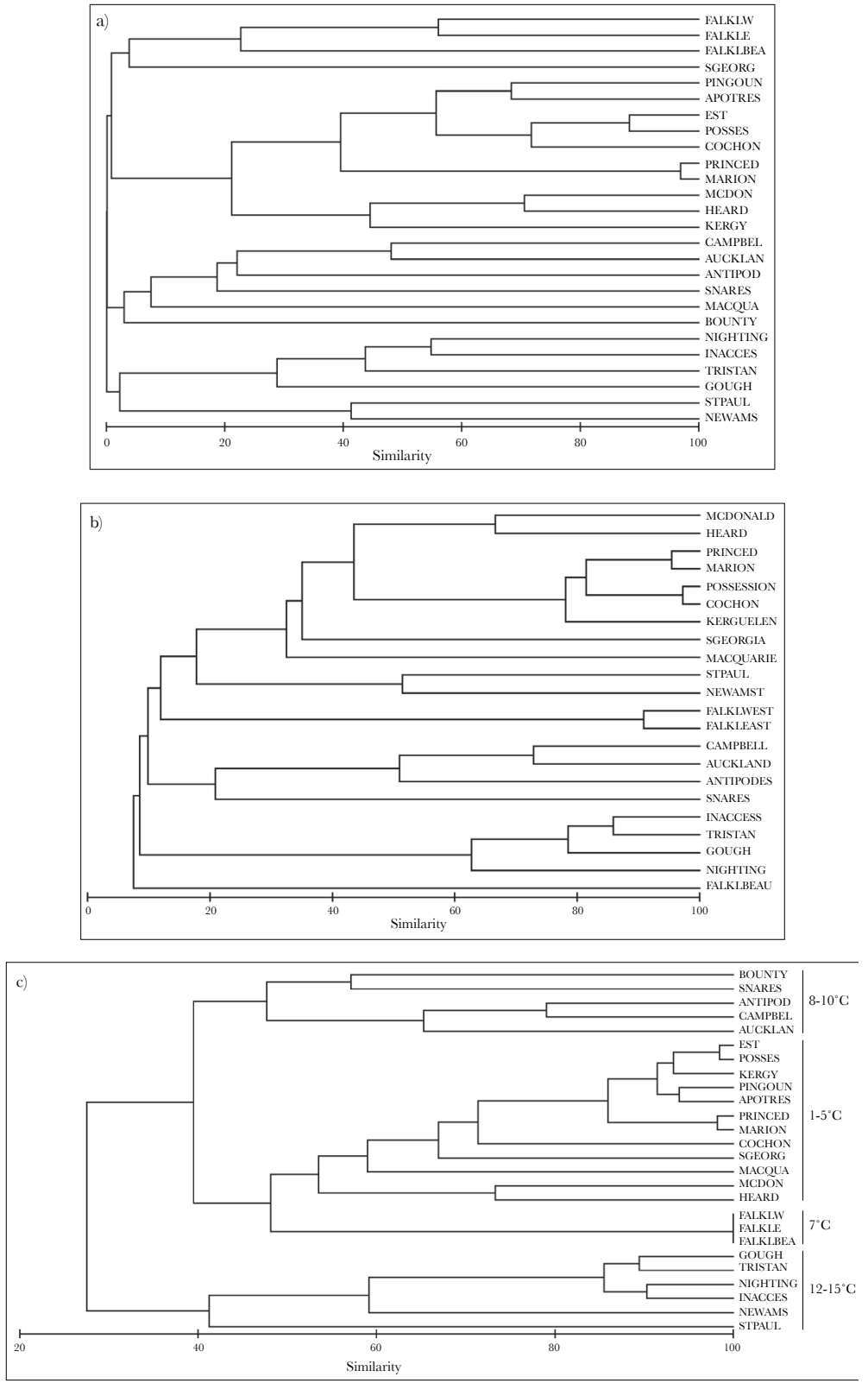

Figure 11.2 Dendrograms, based on cluster analyses using a Bray-Curtis Similarity matrix and Group Averaging, showing relationships among the Southern Ocean island biotas. a) Insects. b) Vascular plants. c) Seabirds. In c, islands of different mean annual temperature are indicated, illustrating the structuring of the faunas according to temperature. Redrawn from Greve et al. 2005. NEWAMS - New Amsterdam Isl.; ANTIPOD - Antipodes Isl.; AUCKLAN - Auckland Isl.; APOTRES- Apotres Isl.; BOUNTY - Bounty Isl.; CAMPBEL - Campbell Isl.; COCHON - Cochon Isl.; EST - Est Isl.; FALKBEA - Beauchene Island; FALKLE - East Falkland; FALKLW - West Falkland; GOUGH - Gough Isl.; HEARD - Heard Isl.; INACCESS - Inaccessible Isl.; KERGY - Kerguelen Isl.; MACQUA - Macquarie Isl. MARION - Marion Isl.; MCDON - McDonald Isl.; NIGHTING - Nightingale Isl.; PINGOUIN - Pingouin Isl.; POSSES - Possession Isl.; PRINCED - Prince Edward Isl.; SGEORG - South Georgia; SNARES - Snares Isl.; STPAUL - St. Paul Isl.; TRISTAN - Tristan da Cunha Isl. 
Further support for this idea comes from two other sources. First, although marine organisms vary considerably in their dispersal ability (Jablonski \& Lutz 1983), they are generally thought to be capable of dispersal over larger areas than is the case for many terrestrial groups (Stanley 1979; Jablonski \& Lutz 1983; Chown 1997). If this is also true of Southern Ocean marine groups (although planktotrophic development is rare - Knox 1994), it might be expected that their biogeographic relationships would be less clearly multiregional than those of terrestrial taxa, and that nestedness would consequently be much higher in marine than in terrestrial assemblages. Much of the literature on the biogeography of marine groups suggests that the fauna is more clearly separated according to their thermal preferences than regional origin (Branch 1994; Knox 1994; Razouls et al. 2000; Sicinski \& Gillet 2002). This is true also of the highly pelagic seabirds (Fig. 11.2c). Whilst more thorough surveys of marine benthic and pelagic fish and invertebrate taxa might alter this situation (de Broyer et al. 2003), recent intensive explorations have revealed biogeographic patterns dominated by a temperature rather than by a regional signal (Gorny 1999; Brandt et al. 1999; Barnes \& De Grave 2001; Selje et al. 2004). Likewise, nestedness of marine groups appears to be high. For example, in the case of the polychaete data provided by Branch (1994), nestedness is very high by comparison with other pelagic taxa such as the seabirds, and certainly much higher than many of the terrestrial taxa examined by Greve et al. (2005).

The second line of evidence supporting the importance of dispersal in determining the historical biogeography of the region comes from small, terrestrial taxa. It has been suggested that small organisms are much more likely to be panmictic than larger ones (Fenchel 1993; Finlay et al. 1996; but see also Wilkinson 2001; Green et al. 2004), and in consequence that speciation is likely to be less common and taxa more widely distributed. McInnes \& Pugh's (1998) analysis of the biogeography of the Antarctic and Southern Ocean island tardigrades showed little in the way of support for a multi-regional hypothesis, but rather indicated subdivision of areas according to climate. Moreover, another small-sized, freshwater/terrestrial group, the testate amoebae, are highly nested and marginally more so than the pelagic seabirds (Greve et al. 2005). Curiously, the bryophyte presence-absence matrix used by Muñoz et al. (2004), which they claimed supports an hypothesis of dispersal by wind across the southern continents and islands, is only slightly less nested than that of the vascular plant matrix examined by Greve et al. (2005) (dl for vascular plants $=0.577$, and for Muñoz et al.'s (2004) bryophyte data = 0.475). Clearly, bryophyte dispersal across the region might not be as efficient as might at first be expected for species that can spread by means of spores and gemmae.

As expected, nestedness is significantly greater in the non-indigenous, or alien, species than in those indigenous to the islands, and the difference between generic and species levels in the former species is half as large as those in the latter. Thus, the same alien species tend to be transported to the islands and there is little regional pattern to this transport, such that genera and species 
have more similar nestedness than is the case for indigenous taxa. However, vagility has as much influence on the patterns found for the alien species as it has on those found in the indigenous species. The influence of dispersal ability on nestedness in the alien species seems to be a consequence of the tendency for similar plant species to be introduced across the region, whereas introduced insects typically are more regional in their origins (Greve et al. 2005).

Whilst the nestedness approach has not resolved the conundrum regarding the origins of the biotas, it has demonstrated that dispersal plays a major role in determining biogeographic patterns in the region, and the way that they are interpreted (see also McDowall 2002; Craig et al. 2003; Muñoz et al. 2004). Therefore, whilst early vicariance may have set the board in the Southern Ocean (Cheshire et al. 1995; McDowall 2002), the later game has clearly been one of dispersal. Indeed, recent studies have not only shown that dispersal must have occurred soon after the islands in the region became subaerial, but also that multiple dispersal events took place (Grobler et al. 2006; Stevens et al. 2006). Today, the rules of this dispersal game are changing as human activity increases across the region and climates warm.

\section{II.2 Ecological biogeography: determinants of richness}

Although the importance of dispersal across the Southern Ocean region is now broadly acknowledged (see previous section and Greve et al. 2005), the likelihood that classic species-area relationships hold for the Southern Ocean has long been considered low. Indeed, for many years the view was held that the effects of glaciation, persistent low temperatures, and considerable isolation are predominantly responsible for patterns of species richness variation across the Southern Ocean islands, and that island area is of much less significance (Gressitt 1970; Kuschel 1971; Abbott 1974; Burger 1985; Chown 1990a). Recent analyses (Chown et al. 1998; Selmi \& Boulinier 2001; Chown et al. 2005) have shown that elements of both classic island biogeography theory (isolation and available area), and the influence of varying energy availability (measured as sea surface temperature) explain variation in richness of terrestrial vascular plants, terrestrial birds and mammals, and pelagic seabirds. In the case of introduced species, human occupation of the islands plays a large role too.

The richness of indigenous vascular plants across the Southern Ocean islands is related to both available area and available energy, irrespective of whether or not the analyses take spatial autocorrelation (see Lennon 2000) into account. This finding is largely in keeping with species energy theory (Wylie \& Currie 1993; Evans et al. 2004). Area is likely to influence species richness both as a consequence of habitat heterogeneity and for reasons of changes in extinction and colonization probability (see MacArthur \& Wilson 1967; Rosenzweig 1995; Ricklefs \& Lovette 1999 for discussion). How precisely variation in energy availability determines variation in species richness is controversial, and might involve both the physiological tolerances of species as well as the ways in which energy is apportioned between individuals and subsequently between species 
(Evans et al. 2004). Nonetheless, the finding that available energy (because water is typically not limiting on these islands, sea surface temperature (SST) can be used as a surrogate of richness - Hawkins et al. 2003) influences richness is typical of most large scale studies (reviews in Hawkins et al. 2003; Willig et al. 2003; Evans et al. 2004; Kalmar \& Currie 2006).

The situation is more complex for the indigenous insects. Depending on the analysis (i.e. including/excluding spatial autocorrelation), distance to the closest continent, indigenous plant richness, area, and SST are all correlates of richness (Chown et al. 1998; Selmi \& Boulinier 2001; Chown et al. 2005). Clearly, dispersal capabilities of the insects and isolation of the islands have been significant in influencing the richness patterns. The influence of energy can also be interpreted in much the same way that it might influence indigenous vascular plant species richness. However, the role of indigenous plant species richness in influencing insect species richness is more controversial. It has long been maintained generally that plant richness might have a substantial influence on herbivore richness (e.g. Gaston 1992; Siemann et al. 1998). However, this idea is contentious and recent analyses have suggested that evidence in favour of a relationship between plant and herbivore richness is perhaps weaker than was once thought, at least at large spatial scales (Hawkins \& Porter 2003; Hawkins \& Pausas 2004). In the present case, it is difficult to determine what the nature is of the relationship between vascular plant and insect richness. Whilst indigenous plant richness is a strong correlate of insect richness (irrespective of analytical approach), one spatially explicit approach suggests that this is a consequence of similar responses of both groups to island area (Selmi \& Boulinier 2001), whilst another does not support this assertion (Chown et al. 2005).

In the case of the birds, pronounced differences exist between the marine, pelagic and the terrestrial species. Island age, vascular plant and insect richness are the most significant correlates of land bird richness (irrespective of the analytical approach). Thus, time for faunal accumulation, in situ evolution, and resource availability have all influenced land bird richness. Although energy availability (as SST) is significant in the univariate models (Chown et al. 1998), it is replaced by perhaps a more direct measure of resource availability (plant and insect richness). Seabird richness, by contrast, is most strongly related to chlorophyll concentration and SST, measures of energy availability, and to area. Seabirds tend to be limited by nest site availability on Southern Ocean islands (Jouventin 1990; Warham 1996), and area provides an effective surrogate measure thereof. At large scales, strong relationships between primary productivity (and sea surface temperature), measures of energy availability, and seabird species richness and abundance have previously been found (Pakhomov \& McQuaid 1996; Chown \& Gaston 1999). Intriguingly, a recent study at global scales has demonstrated that wind energy is also a major correlate of procellariiform species richness (Davies et al., submitted ms.). 
Because many of the introduced land bird species dispersed to the islands (especially the New Zealand sub-Antarctic islands and Macquarie Island) subsequent to introduction elsewhere (Turbott 1990; Young 1995), distance to the closest land mass is a strong correlate of their richness. However, introduced land bird richness is also strongly related to resource availability (in the form of insect and plant richness) as it is for the indigenous terrestrial birds, once again supporting an energy availability argument. In the analyses undertaken by Selmi \& Boulinier (2001) annual numbers of human occupants was also a strong correlate of the richness of introduced land birds at the islands, and number of occupants also typically emerges as the strongest relationship for introduced mammals (Fig. 11.3). In neither case is such an outcome surprising, given that intentional and accidental releases of mammals and birds onto the islands have been widely documented (Frenot et al. 2005). Indeed, it would be astonishing if numbers of human occupants (scientific and logistic personnel as well as numbers of permanent residents for some islands) did not enter models of variation in richness of these groups.

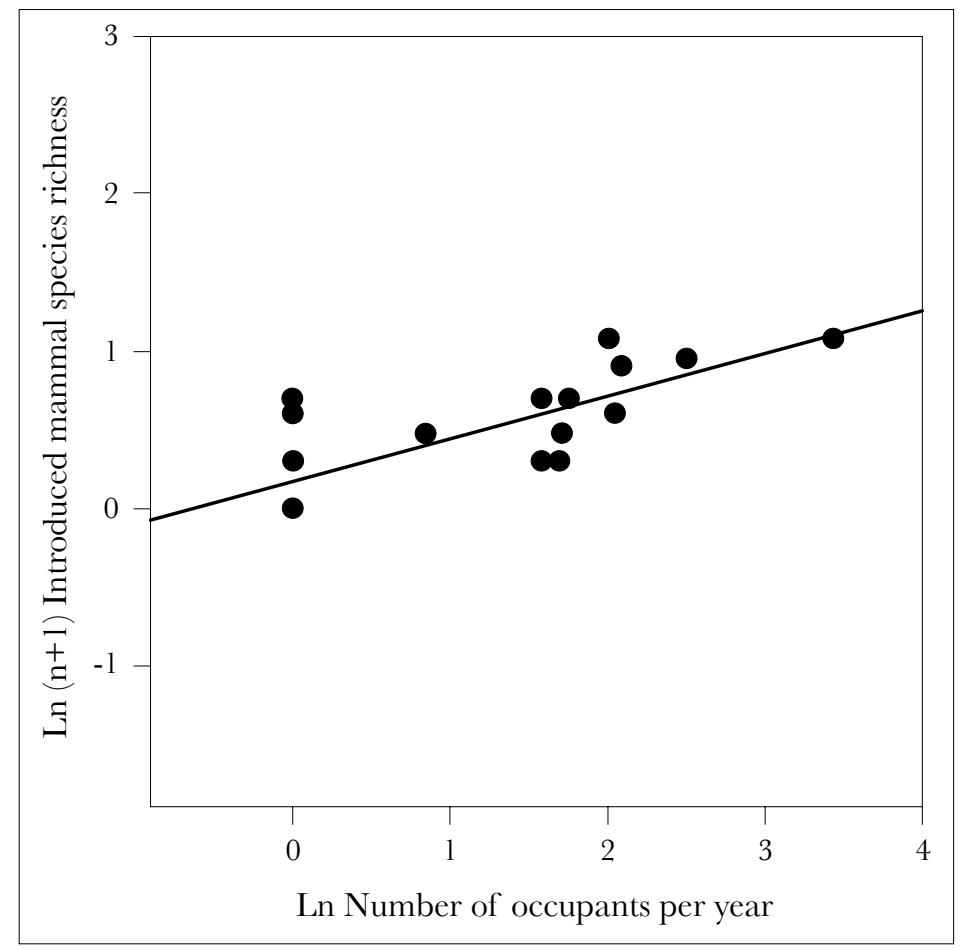

Figure 11.3 Bivariate plot of $\ln (\mathrm{n}+1)$ introduced mammal species richness on $\mathrm{ln}$ number of occupants per year for the Southern Ocean islands. Redrawn from Chown et al. 1998.

Across the Southern Ocean Islands, visitor frequency and energy availability are significant correlates of alien vascular plant and insect species richness (Chown et al. 1998; Selmi \& Boulinier 2001; Chown et al. 2005). These 
correlates suggest that exotic species richness is high in high energy areas for two reasons: the ecological processes that enable large numbers of species to coexist (see Evans et al. 2004 for review), and the historical processes that have meant enhanced propagule pressure as a consequence of high visitor frequency (e.g. Williamson 1996; Lonsdale 1999). However, visitor frequency also covaries positively with both area and energy availability (Chown et al. 2005). Thus, the effects of energy availability and human visitor frequency on the richness of exotic species on these islands are confounded. This situation is not likely to be unique to the Southern Ocean islands because propagule pressure and disturbance, as a consequence of human activities, are major factors influencing invasion success everywhere (Williamson 1996; Lonsdale 1999), and because energy availability and human population density typically covary positively (Rivard et al. 2000; Chown et al. 2003). In consequence, propagule pressure and disturbance, and the ecological processes that enable large numbers of species to coexist (Evans et al. 2004), are likely to be causally interrelated. In consequence, distinguishing the relative importance of the ecological (energy) and historical (human occupancy) effects requires that the latter be held relatively constant. Comparing patterns of invasion on Heard and Gough Islands, which have had virtually identical numbers of visits, but which differ substantially in climate and indigenous species richness, allows this to be done.

Gough Island is comparatively warm, with a mean annual temperature of $11.5^{\circ} \mathrm{C}$ that has remained little changed since the $1950 \mathrm{~s}$ (Jones et al. 2003). It has a well-developed indigenous terrestrial vascular flora (70 species) and is home to 28 indigenous insect species. Heard Island is cold, with a mean annual temperature of $1.7^{\circ} \mathrm{C}$, and extensive, though rapidly receding glaciation. It is species poor, with just 12 indigenous vascular plant and nine indigenous insect species (Chown et al. 2006; Turner et al. 2006). Humans first landed on Gough Island in 1675 . However, until 1802 only one other recorded landing took place. Thereafter, the numbers of visits increased - first for sealing purposes, and later (after 1955) for science (Fig. 11.4), resulting in a total of 239 landings. Heard Island was discovered in 1855, experienced a rapid increase in visits owing to sealing until this resource was exhausted, and is once again experiencing an increase in visits for science and tourism (Fig. 11.4). In total, there have been 232 landings on the island. There are two non-indigenous plant and insect species known from Heard Island, of which the grass Poa annua is thought to have arrived prior to 1955, and the thrip Apterothrips apteris in the early 1990s. Alien species have thus established on average once every 72 years or every 116 visits. Gough Island is highly invaded, with 74 non-indigenous insects and plants generally widespread across the island. These species have established at a rate of on average one every four to five years, or with every third visit (Chown et al. 2005). 


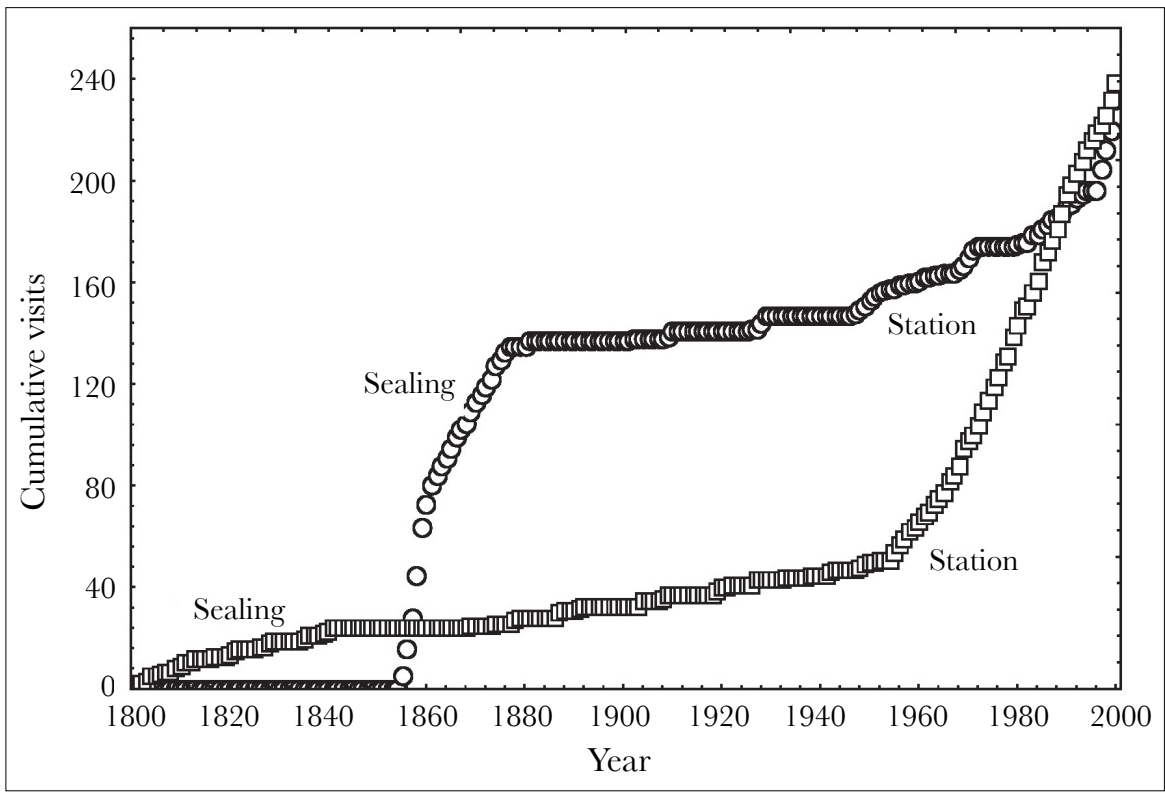

Figure 11.4 Cumulative number of landings at Heard Island (circles) and Gough Island (squares) since 1800. Prior to this time only two landings were made at Gough Island and none at Heard Island. The sealing boom years for each island are indicated, as are the dates at which permanent scientific stations were established (1947-1954 for Heard Island; 1956 onwards for Gough Island. Redrawn from Chown et al. 2005.

These results provide support for the hypothesis that on these islands energy availability is a major correlate of exotic species richness, and presumably a determinant thereof via the ecological processes that result in an association between energy availability, high numbers of individuals and elevated diversity in all species (Chown et al. 2005). Other differences between the islands, such as distance from source areas, or date of human occupation, might account for these patterns, though recent analyses have shown that this is unlikely to be the case (Chown et al. 1998; Selmi \& Boulinier 2001). A more plausible alternative is that climate matching (see Duncan et al. 2003 for recent review) is responsible for these patterns, such that species from more temperate source areas have a higher likelihood of establishing on the warmer Gough Island than on the cooler Heard Island. However, many of the terrestrial exotic species recorded across the Southern Ocean region have established at both cold and warm islands, and are largely weedy European species that have broad tolerances and have established in cold to cool temperate ports in South Africa (Cape Town) and Australia (Hobart), the origin of much shipping to the region (Frenot et al. 2005). Therefore, it does not seem likely that strict physiological intolerance is an entirely adequate explanation of the differential richness of exotic species on Heard and Gough islands. Rather, when visitor frequency is held constant, energy availability is the major correlate of exotic species 
richness, though the exact mechanistic cause of this relationship requires clarification (Chown et al. 2005).

\section{II.3 New developments in phylogeography}

Perhaps the largest gap in our knowledge of the biogeography of the Prince Edward islands, and indeed for the Southern Ocean Islands as a whole, is the absence of area cladograms or related analyses based on molecular systematic (or phylogeographic) information. Although such analyses are starting to become more common in the region (Bargelloni et al. 2000; Burg \& Croxall 2001; Richardson et al. 2003; Allegrucci et al. 2006; Stevens et al. 2006), they are largely lacking for the marine and terrestrial plants and invertebrates.

Those studies that have been undertaken indicate a close coincidence between colonization patterns and the geological and climatological histories of the islands. For example, DNA sequence data suggest that weevils in the genus Ectemnorhinus colonized the Prince Edward Islands 0.43 Ma (Grobler et al. 2006), only 70 ka after the islands' emergence (McDougall et al. 2001). However, even within groups, such as the Ectemnorhinus weevils, there are substantial differences between taxa, such that primers which work well on one group of genera fail to adequately amplify DNA for another. Likewise, searches on GenBank often reveal little but broad similarity between the taxa on the islands and those elsewhere (G.C. Grobler, unpublished data). Thus, the origins of many of the groups, and the relationships between the islands remain enigmatic. Somewhat greater success in determining colonization patterns and relationships has been had among springtails in the genus Cryptopygus and its close relatives (Stevens et al. 2006). This study demonstrated relatively recent $(<2 \mathrm{Ma})$ colonization among sub-Antarctic islands, and older diversification (11-21 Ma) on the Antarctic continent.

Smaller scale, phylogeographic (Avise et al. 1987) and molecular systematic studies have also been undertaken on several islands. In some instances they have revealed cryptic species, and in others complicated phylogeographic patterns. For example, in the former case, two, morphologically almost identical Bothrometopus parvulus-like species coexist on Marion Island rather than the single species recorded to date. Moreover, whilst two Ectemnorhinus species occur on Prince Edward Island, only a single species appears to exist on Marion Island, with a complex genetic structure unrelated to body size (contra Chown 1990b) (Grobler et al. 2006). In the latter case, recent work has shown complex phylogeographic structure of in mites and springtails, related to the climatic and volcanic history of Marion Island (Mortimer \& Jansen Van Vuuren 2006; Myburgh et al. 2007). However, phylogeographic structure in invasive springtails is remarkably simple (often only a single haplotype is present), indicating that the invasion was initiated by few individuals.

These genetic patterns are overlain on a background of complex spatial relationships in assemblage structure that are a function of present ecological 
conditions (McGeoch et al. 2008), as well as substantial spatial variation in morphology and physiology (e.g. Chown \& Klok 2003; Klok \& Chown 2003). It is these intra-island patterns that represent one of the most interesting challenges to biologists at the islands.

\section{II.4 Conclusions}

Although the origins of several groups found on the South Indian Ocean Province Islands and the biogeographic relationships of some of the islands remain controversial, the biogeography of the region is perhaps much less of a mystery than it was in the past. New evidence, such as of the time of emergence of the Kerguelen archipelago (Wallace et al. 2002), the likely previous extent of the landmass in this region, and the relationships between taxa based on molecular systematic evidence (e.g. Stevens et al. 2006), is bound to alter some of the present interpretations. However, it seems likely that the close relationships between the Prince Edward Islands and the other South Indian Ocean Province Islands will continue to enjoy support.

What is perhaps more concerning is the evidence for such high rates of successful establishment of alien species on these islands. For example, the per ship probability of terrestrial invasion for Gough Island is 750 times higher, and for Heard Island 20 times higher, than that found for shipping-associated marine invasions in a recent global survey (Drake \& Lodge 2003; Chown et al. 2005). Moreover, Gaston et al. (2003) have shown that, even taking the likely natural extinction patterns of indigenous species into account, and the fact that probably only 1 out of 10 colonizations results in the successful establishment of an alien insect species (Williamson \& Fitter 1996; but see Jeschke \& Strayer 2005), the rate of successful, human-mediated establishment of alien insects on Gough Island is two to three orders of magnitude greater than the natural background rate. In the context of human-mediated extinctions that are also taking place at a rate two to three orders of magnitude higher than background rates (May et al. 1995), these data suggest that humans are homogenizing the island biotas in two ways. Extinctions reduce the components of diversity that contribute to place distinctiveness, whereas introductions enhance those that contribute to similarity. Because invasive species are often responsible for island extinctions (Blackburn et al. 2004), these two routes to homogenization are closely coupled. Moreover, increasing connectivity across the region owing to science and tourism (Chown \& Gaston 2000), and climatic warming (Frenot et al. 2005), suggest that these problems might be exacerbated in the future in the absence of appropriate conservation action. If this problem includes the transport of species indigenous to particular islands to others (e.g. Tréhen \& Voisin 1984; Ernsting 1993), or the integration of geographically and genetically distinct populations, then the biogeographic signal to noise ratio is likely to become even lower, making interpretation of this complex region more difficult than it has already proven to be. 


\section{II.5 Acknowledgements}

Thanks to Kevin Gaston, Niek Gremmen, Bruce Hull, Melodie McGeoch, and Philip Pugh for discussion, Jesús Muñoz for data on bryophyte distributions, Michelle Greve for running additional nestedness analyses, and Gert Grobler for providing unpublished information.

\section{II.6 References}

Abbott, I. 1974. Number of plant, insect and land bird species on nineteen remote islands in the Southern Hemisphere. Biological Fournal of the Linnean Society 6, 143-152.

Andrássy, I. 1998. Nematodes in the Sixth Continent. Fournal of Nematode Morphology and Systematics 1, 107-186.

Allanson, B.R., Boden, B., Parker, L. \& Duncombe Rae, C. 1985. A contribution to the oceanology of the Prince Edward Islands. In: Siegfried, W.R., Condy, P.R. \& Laws, R.M. (Eds.). Antarctic Nutrient Cycles and Food Webs. Springer-Verlag, Berlin Heidelberg, pp. 38-45.

Allegrucci, G., Carchini, G., Todisco, V., Convey, P. \& Sbordoni, V. 2006. A molecular phylogeny of Antarctic Chironomidae and its implications for biogeographical history. Polar Biology 29, 320-326.

Anderson, G.L., Rova, J.H.E. \& Andersson, L. 2001. Molecular phylogeny of the tribe Anthospermeae (Rubiaceae): Systematic and biogeographic implications. Australian Systematic Botany 14, 231-244.

Avise, J.C., Arnold, J., Ball, R.M., Bermingham, E., Lamb, T., Neigel, J.E., et al. 1987. Intraspecific phylogeography: The mitochondrial DNA bridge between population genetics and systematics. Annual Review of Ecology and Systematics $\mathbf{1 8}$ 489-522.
Bargelloni, L., Marcato, S., Zane, L. \& Partarnello, T. 2000. Mitochondrial phylogeny of notothenoids : a molecular approach to Antarctic fish evolution and biogeography. Systematic Biology 49, 114-129.

Barnes, D.K.A. 2002. Invasions by marine life on plastic debris. Nature $\mathbf{4 1 6}$, 808-809.

Barnes, D.K.A. \& De Grave, S. 2001. Ecological biogeography of southern polar encrusting faunas. Fournal of Biogeography 28, 359-365.

Barrat, A. \& Mougin, J.L. 1974. Donneés numériques sur la zoogéographie de l'avifane Antarctique et Subantarctique. Comité Nationale Français des Recherches Antarctiques 33, 1-18.

Beklemishev, K.V. 1969. Ecology and Biogeography of the Pelagial. Moscow, Nauka Press, pp. 1-291.

Beggs, J.M., Challis, G.A. \& Cook, R.A. 1990. Basement geology of the Campbell Plateau: implications for correlation of the Campbell Magnetic Anomaly System. New Zealand Journal of Geology and Geophysics 33, 401-404.

Blackburn, T.M., Cassey, P., Duncan, R.P., Evans, K.L. \& Gaston, K.J. 2004. Avian extinction and mammalian introductions on oceanic islands. Science 305, 1955-1958. 
Boden, B.P. \& Reid, F.M.H. 1989. Marine plankton diatoms between Cape Town and the Prince Edward Islands (SW Indian Ocean). South African Journal of Antarctic Research 19, 1-49.

Boelhouwers, J., Meiklejohn, I., Holness, S. \& Hedding, D. 2008. Geology, geomorphology and climate change. In: Chown, S.L. \& Froneman, P.W. (Eds.). The Prince Edward Islands. LandSea Interactions in a Changing Ecosystem. African Sun Media, Stellenbosch, pp. 65-96.

Branch, M.L. 1994. The Polychaeta of subantarctic Marion and Prince Edward Islands: Illustrated keys to the species and results of the 1982-1989 University of Cape Town surveys. South African fournal of Antarctic Research 24, 3-52.

Branch, M.L., Arnaud, P.M., Cantera, J. \& Gianakouras, D. 1991a. The benthic Mollusca and Brachiopoda of subantarctic Marion and Prince Edward Islands. South African Fournal of Antarctic Research 21, 45-64.

Branch, M.L., Griffiths, C.L., Kensley, B. \& Sieg, J. 1991b. The benthic Crustacea of subantarctic Marion and Prince Edward Islands:

Illustrated keys to the species and results of the 1982-1989 University of Cape Town surveys. South African Fournal of Antarctic Research 21, 3-44.

Branch, M.L., Jangoux, M., Alva, V., Massin, C.I. \& Stampanato, S. 1993. The Echinodermata of subantarctic Marion and Prince Edward Islands. South African Fournal of Antarctic Research 23, 37-70.

Brandt, A., Linse, K. \& MuhlenhardtSiegel, U. 1999. Biogeography of Crustacea and Mollusca of the Subantarctic and Antarctic regions. Scientia Marina Supplement 63, 383-389.
Broughton, D.A. \& McAdam, J.H. 2002. The Vascular Flora of the Falkland Islands: An Annotated Checklist and Atlas. Falklands Conservation, Stanley.

Brown, J.H. \& Lomolino, M.V. 1998. Biogeography. Sinauer Associates, Sunderland.

Brundin, L. 1966. Transantarctic relationships and their significance as evidenced by chironomid midges. Svenska Vteneskapsakademie Handlunge 11, 1-472.

Burg, T.M. \& Groxall, J.P. 2001. Global relationships amongst black-browed and grey-headed albatrosses: analysis of population structure using mitochondrial DNA and microsatellites. Molecular Ecology 10, 2647-2660.

Burger, A.E. 1985. Terrestrial food webs in the sub-Antarctic: Island effects. In: Siegfried, W.R., Condy, P.R. \& Laws, R.M. (Eds.). Antarctic Nutrient Cycles and Food Webs. Springer, Berlin, pp. 582-591.

Cheshire, A.C., Conran, J.G. \& Hallam, N.D. 1995. A cladistic analysis of the evolution and biogeography of Durvillaea (Phaeophyta). Journal of Phycology 31, 644-655.

Chown, S.L. 1990a. Possible effects of Quaternary climatic change on the composition of insect communities of the South Indian Ocean Province Islands. South African fournal of Science 86, 386-391.

Chown, S.L. 1990b. Speciation in the sub-Antarctic weevil genus Dusmoecetes Jeannel (Coleoptera: Curculionidae). Systematic Entomology 15, 283-296.

Chown, S.L. 1994. Historical ecology of sub-Antarctic weevils (Coleoptera: Curculionidae): patterns and processes on isolated islands. Fournal of Natural History 28, 411-433. 
Chown, S.L. 1997. Speciation and rarity: separating cause from consequence. In: Kunin, W.E. \& Gaston, K.J. (Eds.). The Biology of Rarity. Chapman and Hall, London, pp. 91-109.

Chown, S.L. \& Gaston, K.J. 1999. Patterns in procellariiform diversity as a test of species-energy theory in marine systems. Evolutionary Ecology Research 1, 365-373.

Chown, S.L. \& Gaston, K.J. 2000. Island-hopping invaders hitch a ride with tourists in the Southern Ocean. Nature 408, 637.

Chown, S.L., Greenslade, P. \& Marshall, D.J. 2006. Terrestrial invertebrates of Heard Island. In: Green, K. \& Woehler, E.J. (Eds.). Heard Island: Southern Ocean Sentinel. Surrey and Beatty, Chipping Norton, pp. 91-104.

Chown, S.L., Gremmen, N.J.M. \& Gaston, K.J. 1998. Ecological biogeography of southern ocean islands: Species-area relationships, human impacts, and conservation. American Naturalist 152, 562-575.

Chown, S.L., Hull, B. \& Gaston, K.J. 2005. Human impacts, energy availability, and invasion across Southern ocean islands. Global Ecology and Biogeography 14, 521-528.

Chown, S.L. \& Klok, C.J. 2003. Altitudinal body size clines: latitudinal effects associated with seasonality. Ecography 26, 445-455.

Chown, S.L., Van Rensburg, B.J., Gaston, K.J., Rodrigues, A.S.L. \& Van Jaarsveld, A.S. 2003. Energy, species richness, and human population size: conservation implications at a national scale. Ecological Applications 13, 1233-1241.

Cox, C.B. 2001. The biogeographic regions reconsidered. Fournal of Biogeography 28, 511-523.
Crafford, J.E., Scholtz, C.H. \& Chown, S.L. 1986. The insects of subAntarctic Marion and Prince Edward Islands; with a bibliography of Entomology of the Kerguelen Biogeographical Province. South African Fournal of Antartic Research 16, 42-84.

Craig, D.A., Currie, D.C. \& Vernon, P. 2003. Crozetia Davies (Diptera: Simuliidae): redescription of Cr. crozetensis, Cr. seguyi, number of larval instars, phylogenetic relationships and historical biogeography. Zootaxa 259, 1-39.

Darlington, P.J. 1957. Zoogeography. The Geographical Distribution of Animals. John Wiley, New York.

Darlington, P.J. 1970. A practical criticism of Hennig-Brundin "phylogenetic systematics" and Antarctic biogeography. Systematic Zoology 19, 1-18.

De Broyer, C., Jazdzewski, K. \& Dauby, P. 2003. Biodiversity patterns in the Southern Ocean: lessons from Crustacea. In: Huiskes, A.H.L., Gieskes, W.W.C., Rozema, J., Schorno, R.M.L., Van der Vies, S.M. \& Wolff, W.J. (Eds.). Antarctic Biology in a Global Context. Backhuys Publishers, Leiden, pp. 201-214.

Déharveng, L. 1981. Collemboles des iles subantarctiques de l'Océan Indien Mission J. Travé 1972-1973. Comité National Française des Recherches Antartiques 48, 33-108.

Delettre, Y.R., Frenot, Y., Vernon, P. \& Chown, S.L. 2003. First record of Telmatogeton sp. (Diptera: Chironomidae) at Heard Island. Polar Biology 26, 423-426.

Drake, J.M. \& Lodge, D.M. 2003. Global hot spots of biological invasions: evaluating options for ballast-water management. Proceedings of the Royal Society of London B 271, 575-580. 
Duncan, R.P., Blackburn, T.M. \& Sol, D. 2003. The ecology of bird introductions. Annual Review of Ecology, Evolution, and Systematics 34, 71-98.

Eastman, J.T. 1993. Antarctic Fish Biology. Evolution in a Unique Environment. Academic Press, London, pp 1-322.

Edgar, E. \& Connor, H.E. 2000. Flora of New Zealand. Volume V Gramineae. Manaaki Whenua Press, Lincoln, N.Z.

Ernsting, G. 1993. Observations on life cycle and feeding ecology of two recently introduced predatory beetle species at South Georgia, subAntarctic. Polar Biology 13, 423-428.

Evans, K.L., Warren, P.H. \& Gaston, K.J. 2004. Species-energy relationships at the macroecological scale: a review of the mechanisms. Biological Reviewes 79, 1-25.

Fenchel, T. 1993. There are more small than large species? Oikos 68, 375-378.

Finlay, B.J., Esteban, G.F. \& Fenchel, T. 1996. Global diversity and body size. Nature 383, 132-133.

Frenot, Y., Chown, S.L., Whinam, J., Selkirk, P.M., Convey, P., Skotnici, M., et al. 2005. Biological invasions in the Antarctic: extent, impacts and implications. Biological Reviews 80, 45-72.

Gaston, K.J. 1992. Regional numbers of insect and plant species. Functional Ecology 6, 243-247.

Gaston, K.J. \& Chown, S.L. 1999. Geographic range size and speciation. In: Magurran, A.E. \& May, R.M. (Eds.). Evolution of Biological Diversity. Oxford University Press, Oxford, pp. 236-259.

Gaston, K.J., Jones, A.G., Hänel, C. \& Chown, S.L. 2003. Rates of species introduction to a remote oceanic island. Proceedings of the Royal Society of London B 270, 1091-1098.
Gorodkov, K.B. 1990. Dynamics of a distributional range: a general approach. I. Entomological Review 69, 287-306.

Gorny, M. 1999. On the biogeography and ecology of the Southern Ocean decapod fauna. Scientia Marina Supplement 63, 367-382.

Green, J., Holmes, A.J., Westoby, M., Oliver, I., Briscoe, D., Dangerfield, M., et al. 2004. Spatial scaling of microbial eukaryote diversity. Nature 432, 747-750.

Greene, S.W. \& Walton, D.W.H. 1975. An annotated check list of the subAntarctic and Antarctic vascular flora. Polar Record 17, 473-484.

Gremmen, N.J.M. 1981. The Vegetation of the Subantartic Islands Marion and Prince Edward. Dr. W. Junk, The Hague.

Gremmen, N.J.M. \& Smith, V.R. 2008. Terrestrial vegetation and dynamics. In: Chown, S.L. \& Froneman, P.W. (Eds.). The Prince Edward Islands. LandSea Interactions in a Changing Ecosystem. African Sun Media, Stellenbosch, pp. 215-244.

Gressitt, J.L. 1970. Subantarctic Entomology and Biogeography. Pacific Insects Monograph 23, 295-374.

Greve, M., Gremmen, N.J.M., Gaston, K.J. \& Chown, S.L. 2005. Nestedness of Southern Ocean island biotas: Ecological perspectives on a biogeographic conundrum. Fournal of Biogeography 32, 155-168.

Grobler, G.C., Janse Van Rensburg, L., Bastos, A.D.S., Chimimba, C.T. \& Chown, S.L. 2006. Molecular and morphometric assessment of the taxonomic status of Ectemnorhinus weevil species (Coleoptera, Curculionidae, Brachycerinae) from the sub-Antarctic Prince Edward Islands. Fournal of Zoological Systematics and Evolutionary Research 44, 200-211. 
Hall, K. 1979. Late glacial ice cover and palaeotemperatures on sub-Antarctic Marion Island. Palaeogeography, Palaeoclimatology, Palaeoecology 29, 243-259.

Hall, K.J. 1990. Quaternary glaciations in the southern ocean: sector $0^{\circ}$ long.- $180^{\circ}$ long. Quaternary Science Reviews 9, 217-228.

Hänel, C. \& Chown, S.L. 1999. Fifty years at Marion and Prince Edward Islands: A bibliography of scientific and popular literature. South African Fournal of Science 95, 87-112.

Hawkins, B.A., Field, R., Cornell, H.V., Currie, D.J., Guegan, J.F., Kaufman, D.M., et al. 2003. Energy, water, and broad-scale geographic patterns of species richness. Ecology 84, 3105-3117.

Hawkins, B.A. \& Pausas, J.G. 2004. Does plant richness influence animal richness?: the mammals of Catalonia (NE Spain). Diversity and Distributions 10, 247-252.

Hawkins, B.A. \& Porter, E.E. 2003. Does herbivore diversity depend on plant diversity? The case of California butterflies. American Naturalist 161, 40-49.

Headland, R.K. 1989. Chronological List of Antarctic Expeditions and Related Historical Events. Cambridge University Press, Cambridge.

Holdgate, M.W. 1960. The fauna of the mid-Atlantic islands. Proceedings of the Royal Society of London B $\mathbf{1 5 2}$, 550-567.

Jablonski, D. \& Lutz, R.A. 1983. Larval ecology of marine benthic invertebrates: paleobiological implications. Biological Reviews 58, 21-89.
Jeannel, R. 1964. Biogéographie des terres Australes de l'Océan Indien. Revue Francaise d'Entomologie 31, 319-417.

Jeschke, J.M. \& Strayer, D.L. 2005. Invasion success of vertebrates in Europe and North America. Proceedings of the National Academy of Sciences of the USA 102, 7198-7202.

Jones, A.G., Chown, S.L., Ryan, P.G., Gremmen, N.J.M. \& Gaston, K.J. 2003. Conservation threats on Gough Island: a case study for terrestrial conservation in the Southern Oceans. Biological Conservation 113, 75-87.

Jouventin, P. 1990. Shy albatrosses, Diomedea cauta salvini breeding on Penguin Island, Crozet Archipelago, Indian Ocean. Ibis 132, 126.

Jouzel, J., Barkov, N.I., Barnola, J.M., Bender, M., Chappellaz, J., Genthon, C., et al. 1993. Extending the Vostok ice-core record of palaeoclimate to the penultimate glacial period. Nature 364, 407-412.

Kalmar, A. \& Currie, D.J. 2006. A global model of island biogeography. Global Ecology and Biogeography 15, 72-81.

Kennedy, M. \& Spencer, H.G. 2000. Phylogeny, biogeography, and taxonomy of Australasian teals. Auk 117, 154-163.

Klok, C.J. \& Chown, S.L. 2003. Resistance to temperature extremes in sub-Antarctic weevils: interspecific variation, population differentiation and acclimation. Biological fournal of the Linnean Society 78, 401-414.

Knox, G.A. 1994. The Biology of the Southern Ocean. Cambridge University Press, Cambridge. 
Kuschel, G. 1971. Entomology of the Aucklands and other islands south of New Zealand: Coleoptera: Curculionidae. Pacific Insects Monograph 27, 225-259.

LeMasurier, W.E. \& Thomson, J.W. 1990. Volcanoes of the Antarctic Plate and Southern Oceans. American Geophysical Union, Washington.

Lennon, J.J. 2000. Red-shifts and red herrings in geographical ecology. Ecography 23, 101-113.

Lewis, P.N., Hewitt, C.L., Riddle, M. \& McMinn, A. 2003. Marine introductions in the Southern Ocean: an unrecognised hazard to biodiversity. Marine Pollution Bulletin 46, 213-223.

Lewis Smith, R.I. 1984. Terrestrial plant biology of the sub-Antarctic and Antarctic. In: Laws, R.M. (Ed.). Antarctic Ecology Vol. 1. Academic Press, London, pp. 61-162.

Livemore, R., Nankivell, A., Eagles, G. \& Morris, P. 2005. Paleogene opening of the Drake Passage. Earth and Planetary Science Letters 236, 459-470.

Lockhart, P.J., McLenachan, P.A., Harell, D., Glenny, D., Hudson, D. \& Jenson, U. 2001. Phylogeny, radiation, and transoceanic dispersal of New Zealand alpine buttercups: Molecular evidence under split decomposition. Annals of the Missouri Botanic Garden 88, 458-477.

Lomolino, M.V. 1996. Investigating causality of nestedness of insular communities: selective immigrations or extinctions? Fournal of Biogeography 23, 699-703.

Lonsdale, W.M. 1999. Global patterns of plant invasions and the concept of invasibility. Ecology 80, 1522-1536.

MacArthur, R.H. \& Wilson, E.O. 1967. The Theory of Island Biogeography. Princeton University Press, Princeton.
Marshall, D.J., Gremmen, N.J.M., Coetzee, L., OConnor, B.M., Pugh, P.J.A., Theron, P.D., et al. 1999. New records of Acari from the subAntarctic Prince Edward Islands. Polar Biology 21, 84-89.

Marshall, J.E.A. 1994. The Falkland Islands: a key element in Gondwana paleogeography. Tectonics 13, 499-514.

May, R.M., Lawton, J.H. \& Stork, N.E. 1995. Assessing extinction rates. In: Lawton, J.H. \& May, R.M. (Eds.). Extinction Rates. Oxford University Press, Oxford, pp. 1-24.

McDougall, I., Verwoerd, W. \& Chevallier, L. 2001. K-Ar geochronology of Marion Island, Southern Ocean. Geological Magazine 138, 1-17.

McDowall, R.M. 2002. Accumulating evidence for a dispersal biogeography of southern cool temperate freshwater fishes. Journal of Biogeography 29, 207-219.

McGeoch, M.A., le Roux, P.C., Hugo, E.A. \& Nyakatya, M. 2008. Spatial variation in the terrestrial biotic system. In: Chown, S.L. \& Froneman, P.W. (Eds.). The Prince Edward Islands. Land-Sea Interactions in a Changing Ecosystem. African Sun Media, Stellenbosch, pp. 245-276.

McInnes, S.J. \& Pugh, P.J.A. 1998. Biogeography of limno-terrestrial Tardigrada, with particular reference to the Antarctic fauna. Fournal of Biogeography 25, 31-36.

Morrone, J.J. 1998. On Udvardy's Insulantarctica province: a test from the weevils (Coleoptera: Curculionoidea). Fournal of Biogeography 25, 947-955. 
Mortimer, E. \& Jansen Van Vuuren, B. 2006. Phylogeography of Eupodes minutus (Acari: Prostigmata) on subAntarctic Marion Island reflects the impact of historical events. Polar Biology 30, 47 1-76.

Muñoz, J., Felicísimo, A.M., Cabezas, F., Burgaz, A.R., Martínez, I. 2004. Wind as a long-distance dispersal vehicle in the Southern Hemisphere. Science 304, 1144-1 147.

Myburgh, M., Chown, S.L., Daniels, S.R. \& Jansen Van Vuuren, B. 2007. Population structure, propagule pressure, and conservation biogeography in the sub-Antarctic: lessons from indigenous and invasive springtails. Diversity and Distributions 13, 143-154.

Pakhomov, E.A. \& Chown, S.L. 2003. The Prince Edward Islands: Southern Ocean Oasis. Ocean Yearbook 17, 348-379.

Pakhomov, E.A. \& Froneman, P.W. 2000. Composition and spatial variability of macroplankton and micronekton within the Antarctic Polar Frontal Zone of the Indian Ocean during austral autumn 1997. Polar Biology 23, 410-419.

Pakhomov, E.A. \& McQuaid, C.D. 1996. Distribution of surface zooplankton and seabirds across the southern ocean. Polar Biology 16, 271-286.

Patterson, B.D. \& Atmar, W. 1986. Nested subsets and the structure of insular mammalian faunas and archipelagos. Biological fournal of the Linnean Society 28, 65-82.

Pugh, P.J.A. 1993. A synonymic catalogue of the Acari from Antarctica, the sub-Antarctic Islands and the Southern Ocean. Fournal of Natural History 27, 323-421.
Pugh, P.J.A. 2004. Biogeography of spiders (Araneae: Arachnida) on the islands of the Southern Ocean. Fournal of Natural History 38, 1461-1487.

Pugh, P.J.A., Dartnall, H.J.G. \& McInnes, S.J. 2002. The non-marine Crustacea of Antarctica and the islands of the Southern Ocean: biodiversity and biogeography. Fournal of Natural History 36, 1047-1103.

Pugh, PJ.A. \& Scott, B. 2002. Biodiversity and biogeography of non-marine Mollusca on the islands of the Southern Ocean. Fournal of Natural History 36, 927-952.

Razouls, S., Razouls, C. \& De Bovee, F. 2000. Biodiversity and biogeography of Antarctic copepods. Antarctic Science 12, 343-363.

Richardson, J.E., Fay, M.F., Cronk, Q.C.B. \& Chase, M.W. 2003. Species delimitation and the origin of populations in island representatives of Phylica (Rhamnaceae). Evolution 57, 816-827.

Ricklefs, R.E. \& Lovette, I.J. 1999. The roles of island area per se and habitat diversity in the species-area relationship of four Lesser Antillean faunal groups. Fournal of Animal Ecology 68, 1142-1160.

Rivard, D.H., Poitevin, J., Plasse, D., Carleton, M. \& Currie, D.J. 2000. Changing species richness and composition in Canadian national parks. Conservation Biology 14, 1099-1109.

Rosenzweig, M.L. 1995. Species Diversity in Space and Time. Cambridge University Press, Cambridge.

Scott, L. \& Hall, K.J. 1983. Palynological evidence for interglacial vegetation cover on Marion Island, subantarctic. Paleogeography, Paleoclimatology and Paleoecology 41, 35-43. 
Selje, N., Simon, M. \& Brinkhoff, T. 2004. A newly discovered Roseobacter cluster in temperate and polar oceans. Nature 427, 445-448.

Selmi, S. \& Boulinier, T. 2001. Ecological biogeography of Southern Ocean Islands: The importance of considering spatial issues. American Naturalist 158, 426-437.

Sicinski, J. \& Gillet, P. 2002. Biogeographical affinities of polychaets from Iles Crozet. Antarctic Science 14, 353-363.

Siemann, E., Tilman, D., Haarstad, J. \& Richie, M. 1998. Experimental tests of the dependence of arthropod diversity on plant diversity. American Naturalist 152, 738-750.

Skottsberg, C. 1960. Remarks on the plant geography of the southern cold temperate zone. Proceedings of the Royal Society of London B 152, 447-457.

Slabber, S. \& Chown, S.L. 2002. The first record of a terrestrial crustacean, Porcellio scaber (Isopoda, Porcellionidae), from sub-Antarctic Marion Island. Polar Biology 25, 855-858.

Smith, S.D.A. 2002. Kelp rafts in the Southern Ocean. Global Ecology and Biogeography 11, 67-69.

Stanley, S.M. 1979. Macroevolution. Pattern and Process. Johns Hopkins University Press, Baltimore.

Stevens, M.I., Greenslade, P., Hogg, I.D. \& Sunnucks, P. 2006. Southern Hemisphere springtails: could any have survived glaciation of Antarctica? Molecular Biology and Evolution 23, 874-882.

Tréhen, P. \& Voisin, J.-F. 1984. Sur la présence de Merizodus soledadinus Guérin à Kerguelen (Coléoptères Trechidae). L'Entomologiste 40, 53-54.
Turbott, E.G. 1990. The Checklist of the Birds of New Zealand and the Ross Dependency, Antarctica. 3rd ed. New Zealand Ordnance Survey, Wellington.

Turner, P.A.M., Scott, J.J. \& Rozefelds, A.C. 2006. Probable long distance dispersal of Leptinella plumosa Hook. f. to Heard Island: habitat, status and discussion of its arrival. Polar Biology 29, 160-168.

Udvardy, M.D.F. 1987. The biogeographical realm Antarctica: a proposal. Fournal of the Royal Society of New Zealand 17, 187-194.

Valdebenito, H.A., Stuessy, T.F. \& Crawford, D.J. 1990. A new biogeographic connection between islands in the Atlantic and Pacific Oceans. Nature 347, 549-550.

Van de Vijver, B. \& Beyens, L. 1999. Biogeography and ecology of freshwater diatoms in Subantarctica: a review. Fournal of Biogeography 26, 993-1000.

Van der Spoel, S. \& Heyman, R.P. 1983. A Comparative Atlas of Zooplankton. Biological Patterns in the Oceans. Springer Verlag, Berlin.

Wagstaff, S.J. \& Garnock-Jones, P.J. 1998. Evolution and biogeography of the Hebe complex (Scrophulariaceae) inferred from ITS sequences. New Zealand Journal of Botany 36, 425-437.

Wallace, P.J., Frey, F.A., Weis, D. \& Coffin, M.F. 2002. Origin and evolution of the Kerguelen Plateau, Broken Ridge, and Kerguelen Archipelago: Editorial. Journal of Petrology 43, 1 105-1 108.

Warham, J. 1996. The Behaviour, Population Biology and Physiology of the Petrels. Academic Press, London.

Whittaker, R.J. 1998. Island Biogeography.

Ecology, Evolution, and Conservation. Oxford University Press, Oxford. 
Wilkinson, D.M. 2001. What is the upper size limit for cosmopolitan distribution in free-living microorganisms? Journal of Biogeography 28, 285-291.

Williamson, M. 1996. Biological Invasions. Chapman and Hall, London.

Williamson, M. \& Fitter, A. 1996. The varying success of invaders. Ecology 77, 1661-1666.

Willig, M.R., Kaufman, D.M. \& Stevens, R.D. 2003. Latitudinal gradients of biodiversity: pattern, process, scale and synthesis. Annual Review of Ecology and Systematics 34, 273-309.
Wright, D.H., Patterson, B.D., Mikkelson, G.M., Cutler, A. \& Atmar, W. 1998. A comparative analysis of nested subset patterns of species composition. Oecologia 113, 1-20.

Wylie, J.L. \& Currie, D.J. 1993. Speciesenergy theory and patterns of species richness: I. Patterns of bird, angiosperm, and mammal richness on islands. Biological Conservation 63, 137-144.

Young, E.C. 1995. Conservation values, research and New Zealand's responsibilities for the Southern Ocean Islands and Antarctica. Pacific Conservation Biology 2, 99-112. 